\title{
Elaboration and characterization of pectin-gellan films added with concentrated supernatant of Streptococcus infantarius fermentations, and EDTA: effects on the growth of Escherichia coli, Staphylococcus aureus and Listeria monocytogenes in a Mexican cheese medium, and physical-mechanical properties
}

\author{
Perla-Yesenia JIMÉNEZ-VILLEDA ${ }^{1}$, Adriana-Inés RODRÍGUEZ-HERNÁNDEZ¹, Ma.-del-Rocío LÓPEZ-CUELLAR ${ }^{1}$,
} Melitón-Jesús FRANCO-FERNÁNDEZ ${ }^{1}$, Norberto CHAVARRÍA-HERNÁNDEZ ${ }^{1 *}$

\begin{abstract}
Films were prepared with $0.2 \%$ (w/v) gellan gum, $1 \%(\mathrm{w} / \mathrm{v}$ ) citric pectin, $0.5 \%$ (w/v) glycerol, $5 \mathrm{mM} \mathrm{CaCl}, 0.05 \mathrm{M}$ Ethylenediaminetetraacetic acid (EDTA), and different concentrations of an antimicrobial activity-concentrated supernatant (AMC) obtained from fermentations of Streptococcus infantarius, which produces bacteriocin-like inhibitory substances (i.e., treatments F1, F2 and F3 with 75, 90 and 120 arbitrary units $(\mathrm{AU}) / \mathrm{mL}$, respectively). The treatments were based on a minimum-inhibitory-concentration (i.e., AMC, $90 \mathrm{AU} / \mathrm{mL}$, plus EDTA, $0.05 \mathrm{M}$ ) for Escherichia coli, Staphylococcus aureus and Listeria monocytogenes growing in brain-heart-infusion medium at $35^{\circ} \mathrm{C}$. The films hindered the bacterium growth in selective media: E. coli-MacConkey, S. aureus-Baird Parker and L. monocytogenes-Oxford, during 30 days at $25^{\circ} \mathrm{C}$. Moreover, the F2 films entirely inhibited the growth of the tested bacteria in a Mexican cheese medium, in 7 -day cultures at $35^{\circ} \mathrm{C}$; contrariwise, controls with no film exhibited bacterial growths in the range $10^{7}-10^{9} \mathrm{CFU} / \mathrm{g}$. The physical-mechanical properties of the films were changed by the addition of EDTA-AMC, being (F2 film)/(control-film with no AMC nor EDTA): Young's modulus (MPa), 1,394/707; Elongation at break (\%), 1.9/9.3; Stress at break (MPa), 5.7/12.6; Water Vapour Permeability $\left(10^{-11} \mathrm{~g} \mathrm{~m} \mathrm{~Pa}^{-1} \mathrm{~s}^{-1} \mathrm{~m}^{-2}\right)$, $3 / 20$, and Oxygen Permeability $\left(10^{-12} \mathrm{~g} \mathrm{~m} \mathrm{~Pa}^{-1} \mathrm{~s}^{-1} \mathrm{~m}^{-2}\right), 1.9 / 1.2$.
\end{abstract}

Keywords: lactic acid bacterium; bacteriocins; biopreservation; mechanical properties; gas permeability.

Practical Application: Development of a biodegradable-film containing pectin, gellan, EDTA and antimicrobial substances produced by Streptococcus infantarius, for an effective inhibition of pathogen bacteria like Escherichia coli, Staphylococcus aureus and Listeria monocytogenes, that would contaminate the surface of foods like Mexican fresh cheese.

\section{Introduction}

The food packaging research is of worldwide interest due to food safety matters, among others (Campos et al., 2010). Specifically, research dealing with the packaging of dairy products, particularly cheese, encompasses studies concerning both fresh and ripened cheese; for example, Brazilian "Prato" cheese (Marques et al., 2017); Spanish "Zamorano" ripened sheep cheese (Otero et al., 2014), and Egyptian soft white cheese (Youssef et al., 2016), among others. Moreover, foodborne disease episodes due to cheese consumption have occurred affecting people. Examples of this are: cheese related listeriosis outbreaks in Austria, Germany and Czech Republic (Fretz et al., 2010), Portugal (Magalhães et al., 2015) and USA (Silk et al., 2013); Escherichia coli O157:H7 infection associated with fresh cheese curds in Wisconsin (Durch et al., 2000); Staphylococcus aureus food poisoning outbreaks linked to raw milk semi-hard, raw milk soft, sheep's milk and sliced soft cheese in France (13 outbreaks were reported by Kérouanton et al. (2007) between 1981 and 2002).
Concerning the antimicrobial packaging for the bioconservation of cheese, one alternative is the use of biodegradable polymer films added with bacteriocins as natural antimicrobial agents (Marques et al., 2017; Ollé Resa et al., 2016). Bacteriocins are small peptides, ribosomally synthesized by certain bacterial strains, that are active against other bacteria, with multiple biotechnological applications including food conservation, being nisin the only bacteriocin with GRAS status (López-Cuellar et al., 2016). In order to increase the antimicrobial spectrum in bacteriocin applications, they are frequently used in combination with other agents, as the chelator Ethylenediaminetetraacetic acid (EDTA), which contributes to make the bacterium outer membranes more permeable. Thus, the use of bacteriocins in combination with EDTA would be more effective against bacteria, including the inhibition of Gram negative bacteria like Escherichia coli (Vaara, 1992). Furthermore, some biopolymers do exhibit an antimicrobial activity, that would contribute to a more effective antimicrobial food packaging. This is the case of pectins (Calce et al., 2014; Jindal et al., 2013) and chitosan (Aider, 2010). 
The present article reports the main results concerning the preparation and characterization of films containing gellan gum and citric pectin, added with EDTA and antimicrobial activity-concentrated supernatant (AMC) from fermentations of the lactic acid bacterium, Streptococcus infantarius, which produces bacteriocin-like inhibitory substances. The films were tested against Escherichia coli, Staphylococcus aureus and Listeria monocytogenes grown in specific selective media and in a Mexican fresh cheese medium. Several film physical-mechanical properties were also determined: Young's modulus, stress and elongation at break, water vapour permeability and oxygen permeability, all of them important to consider in defining possible food packaging applications.

\section{Materials and methods}

\subsection{Biological specimens}

Streptococcus infantarius was kindly provided by C. Wacher-Rodarte (FQ-UNAM, Mexico). This strain was isolated from Pozol, a traditional fermented Mexican beverage (Tavera-Montes, 2010).

Escherichia coli ATCC-25922, Staphylococcus aureus ATCC-25923 and Listeria monocytogenes CFQ-103, were kindly provided by G. Díaz-Ruiz (FQ-UNAM, Mexico).

All bacteria were conserved at $-80^{\circ} \mathrm{C}$ in $20 \% \mathrm{v} / \mathrm{v}$ glycerol.

\subsection{Culture media}

Brain heart infusion broth, BHI (Bioxon ${ }^{\circledR}$ México). MacConkey Agar (Sigma-Aldrich). Baird Parker Agar (BD ${ }^{\mathrm{TM}}$ DIFCO, France). Oxford Agar (BD ${ }^{\mathrm{TM}}$ DIFCO, France). De Man-Rogosa-Sharpe broth, MRS (BD ${ }^{\mathrm{TM}}$ DIFCO, France).

Mexican fresh cheese medium (MCh): 4.4\% (w/v) Mexican fresh cheese (Dairy Products Workshop, ICAp-UAEH), 1.5\% (w/v) bacto-agar (BD ${ }^{\mathrm{TM}}$ DIFCO, France). The cheese used was made with pasteurised cow milk, yielding an average of $0.84 \%(\mathrm{w} / \mathrm{v})$ protein and $0.1 \%(w / v)$ fat (Hnosko et al., 2009) into the whole medium.

\subsection{Functional additives and reagents}

A batch of an antimicrobial activity-concentrated supernatant (AMC) from a three litter-S. infantarius fermentation, was obtained according to López-Ortega (2014). The AMC contained bacteriocin-like inhibitory substances with an antimicrobial activity of 6,400 arbitrary units $(\mathrm{AU}) / \mathrm{mL}$, determined by the critical dilution method (Nuñez et al., 1996; Sánchez-Reyes, 2014).

Ethylenediaminetetraacetic acid (EDTA) disodium salt dehydrate, Sigma-Aldrich, Lot\# SLBM9213V. Citric pectin, $\mathrm{GENU}^{\circledR}$ Pectin, DE=36\%, CP-Kelco, USA. Low acyl Gellan gum, Kelcogel, CP-Kelco, USA. Glycerol, Química Meyer, Mexico. Calcium chloride $\left(\mathrm{CaCl}_{2}\right)$ JT Baker, Mexico.

\subsection{Minimal inhibitory concentration of the functional additives}

The determination of the minimal inhibitory concentration of AMC with EDTA, was carried out based on procedures described by Wiegand et al. (2008). Triplicate wells of microtiter plates (Corning ${ }^{\circledR} \operatorname{Costar}^{\circledR}$ ) were filled to $220 \mu \mathrm{L}$ per well, with blends of $24 \mathrm{~h}$-old culture broths of bacteria (E. coli, S. aureus or L. monocytogenes in $\mathrm{BHI}$ ), AMC, EDTA and fresh $\mathrm{BHI}$, to give initial concentrations of $4 \times 10^{4}-7 \times 10^{4}$ bacterial colony-forming units $(\mathrm{CFU}) / \mathrm{mL}$, in presence of the combination of $\mathrm{AMC}$ and EDTA at concentrations of $0,75,90,200$ and $400 \mathrm{AU} / \mathrm{mL}$, and $0,1 \times 10^{-3}, 2 \times 10^{-3}, 4 \times 10^{-3}, 8 \times 10^{-3}, 2 \times 10^{-2}$ and $5 \times 10^{-2} \mathrm{M}$, respectively. Then, plates were incubated at $35^{\circ} \mathrm{C}$ and bacterial growth inhibition was evaluated after $24 \mathrm{~h}$.

\subsection{Preparation of the antimicrobial films}

Three functional film treatments were tested (F1, F2 and F3) and the control (FC). All filmogenic solutions contained $1 \%(\mathrm{w} / \mathrm{v})$ citric pectin, $0.2 \%(\mathrm{w} / \mathrm{v})$ Gellan gum, $0.5 \%(\mathrm{w} / \mathrm{v})$ glycerol and $5 \mathrm{mM} \mathrm{CaCl}$. The F1, F2, F3 and FC films contained [EDTA (M)/AMC $(\mathrm{AU} / \mathrm{mL})$ ] ratios of $0.05 / 75,0.05 / 90$, $0.05 / 120$ and $0 / 0$, respectively. The film preparation method was based on a previous report (Calderón-Aguirre et al., 2015). The polymers were dissolved in distilled water and heated at $60-65^{\circ} \mathrm{C}$ during $40 \mathrm{~min}$, to add glycerol and $\mathrm{CaCl}$; then increasing heat to rise $75^{\circ} \mathrm{C}$. Mixing continued another $30 \mathrm{~min}$; followed by the addition of the antimicrobial additives. Then, each batch of $645 \mathrm{~g}$ of filmogenic solution was poured into a Teflon ${ }^{\circledR}$ cast $\left(\mathrm{EKCO}^{\circledR}, 39.5 \times 27 \times 2 \mathrm{~cm}\right.$ ) and dried in an oven (Shel-Lab, 1380FX) at $35^{\circ} \mathrm{C}$ during $17 \mathrm{~h}$.

The prepared films were then conditioned into a desiccator during $48 \mathrm{~h}$ at $50-55 \% \mathrm{RH}$ and $23^{\circ} \mathrm{C}$. The average thickness of films was measured at five points each one with a micrometer to the nearest $0.0001 \mathrm{~mm}$ (Truper, Mexico).

\subsection{Antimicrobial film effects on Escherichia coli, Staphylococcus aureus and Listeria monocytogenes growing in selective media}

Escherichia coli, S. aureus and L. monocytogenes were grown separately in cap tubes with $5 \mathrm{~mL}$ of BHI during $24 \mathrm{~h}$ at $35^{\circ} \mathrm{C}$; then, appropriate dilutions of each bacterium culture were done using sterile isotonic salt solution, $0.9 \%(\mathrm{w} / \mathrm{v}) \mathrm{NaCl}$, to spread $200 \mu \mathrm{L}$ of a convenient dilution inoculating $25 \mathrm{CFU}$ per plate (Interlux, $60 \times 15 \mathrm{~mm}$ ) with the corresponding selective medium: MacConkey, Baird Parker and Oxford, respectively. Then, each inoculated agar plate was covered with a $6 \mathrm{~cm}$-diameter circular film, previously disinfected with UV radiation during $24 \mathrm{~h}$ (12 h each side) in a Labconco ${ }^{\circledR}$ Class II Type A2 safety cabinet. Later on, the cultures were incubated at $25^{\circ} \mathrm{C}$ during 30 days in a Ríos-Rocha S.A. EC-33 incubator with a mean relative humidity, $\mathrm{RH}$, of $40 \%$. The films F1, F2, F3 and FC, and a control without film (NF) were tested by triplicate.

\subsection{Antimicrobial film effects on Escherichia coli, Staphylococcus aureus and Listeria monocytogenes growing in a Mexican fresh cheese medium}

Escherichia coli, S. aureus and L. monocytogenes were grown separately in cap tubes with $5 \mathrm{~mL}$ of BHI during $24 \mathrm{~h}$ at $35^{\circ} \mathrm{C}$; then proper dilutions of each bacterium culture were done using sterile isotonic salt solution for spreading $200 \mu \mathrm{L}$ of an appropriate dilution having $100 \mathrm{CFU}$, per plate (Interlux, $60 \times 15 \mathrm{~mm}$ ) containing $\mathrm{MCh}$ medium. Later, the surface of 
the inoculated plates was covered with $6 \mathrm{~cm}$-diameter circular films, previously disinfected with UV radiation during $24 \mathrm{~h}$ ( 12 h each side) in a Labconco ${ }^{\circledR}$ Class II Type A2 safety cabinet. The cultures were then incubated at $35^{\circ} \mathrm{C}$ for 7 days, taking samples at $\mathrm{t}=0,1,3,5$ and 7 days, by triplicate. Every sample (1 plate containing $5 \mathrm{~mL}$ agar) was homogenized within $45 \mathrm{~mL}$ peptone water in a Seward Stomacher ${ }^{\circledR} 400$ Circulator, at $300 \mathrm{rpm}$ during $5 \mathrm{~min}$. Later, viable counts were prepared by homogenate-decimal dilutions, then mixing $1 \mathrm{~mL}$ samples into BHI soft agar plates (Interlux, $90 \times 15 \mathrm{~mm}$ ) to be incubated at $35^{\circ} \mathrm{C}$ during $24 \mathrm{~h}$. Based on results obtained in Section 2.6, both F2 and FC treatments were tested, and bacterium-inoculated (NF) plates with no film as controls; all carried out by triplicate. The initial viable count $\left(\mathrm{X}_{0} ; \mathrm{CFU} / \mathrm{g}\right)$, the maximum bacterium concentration $\left(\mathrm{X}_{\max } ; \mathrm{CFU} / \mathrm{g}\right)$, the multiplication factor $\left(\left(\mathrm{X}_{\max } / \mathrm{X}_{0}\right)\right.$, dimensionless) and the maximum growth rate $\left(\mu_{\max } ; h^{-1}\right)$ were computed for each tested bacterium.

\subsection{Mechanical characterization of the antimicrobial films}

The mechanical characterization of the F2 and FC films was done according to the ASTM D882-10 Standard Test Method (American Society for Testing and Materials, 2010) in a Texture Analyser TA plus Lloyd. Every film sample was cut into the "dog-bone" shape (Type M-I tension test specimen) according to the standard ASTM D638M-93 (American Society for Testing and Materials, 1993). The samples were then conditioned during $48 \mathrm{~h}$ at $50-55 \% \mathrm{RH}$ and $25^{\circ} \mathrm{C}$. Afterwards, samples were gripped in the texture analyser with an initial separation of $0.05 \mathrm{~m}$. The tensile tests were carried out at a cross head speed of $1 \mathrm{~mm} / \mathrm{s}$. At least 30 replicates per film treatment were carried out, to determine the stress-Hencky strain function of the samples through the force-distance data. Specimens that failed at the grip contact point were discarded. The Young's modulus (EM; MPa) was determined through the slope of the linear region of the stress-strain curves. The ultimate mechanical properties of the films, stress $\left(\sigma_{\mathrm{T}, \max } ; \mathrm{MPa}\right)$ and elongation at break $\left(\mathrm{E}_{\max } ; \%\right)$ were determined at the rupture point (Calderón-Aguirre et al., 2015).

\subsection{Water vapour permeability of the antimicrobial films}

The water vapour permeability (WVP) of F2 and FC films was determined according to the standard method ASTM E96-00 (American Society for Testing and Materials, 2000). Film disks, previously equilibrated at $53 \% \mathrm{RH}$ and $25^{\circ} \mathrm{C}$ during $48 \mathrm{~h}$, were mounted on aluminium permeation cells containing silica gel $(0 \% \mathrm{RH})$; then the cups were placed within a cabinet which was previously equilibrated at $75 \pm 2 \% \mathrm{RH}$ and $23 \pm 2{ }^{\circ} \mathrm{C}$ during $24 \mathrm{~h}$. Later, the cups were weighed every hour during $8 \mathrm{~h}$. Four runs were done per treatment, and the WVP values were determined according to Aguirre-Loredo et al. (2014).

\subsection{Oxygen permeability of the antimicrobial films}

The oxygen permeability $\left(\mathrm{PO}_{2}\right)$ of the films F2 and FC was determined in accordance to the standard ASTM D1434-82 (American Society for Testing and Materials, 1982) by means of a film-package permeability tester (Labthink VAC-V2, China). Films were conditioned at $50-55 \% \mathrm{RH}$ during $48 \mathrm{~h}$ to be mounted into the chambers of the tester. The tests were performed at $25^{\circ} \mathrm{C}$, using research-grade high-purity (99.998\%) oxygen gas (34161, INFRA ${ }^{\circledR}$ México). All runs were carried out in the quadruple precision.

\subsection{Statistical analysis}

All data are presented as the mean \pm standard deviation of each treatment. Data were analysed for statistical significance through the analysis of variance (ANOVA) followed by the Tukey test $(\mathrm{p}<0.05)$. Differences between pairs of means were assessed through the t-test $(\mathrm{P}<0.05)$ (SigmaPlot 12.5, SPSS Inc., USA).

\section{Results and discussion}

\subsection{Antimicrobial activity of the films}

The concentrated supernatant (AMC) obtained from the S. infantarius-culture broth exhibited antimicrobial activities against both Listeria monocytogenes and Staphylococcus aureus, but apparently did not affect Escherichia coli. In order to elaborate a bioactive film, capable to hinder the growth of the three bacteria (i.e., E. coli, S. aureus and L. monocytogenes), the metal chelator EDTA was incorporated into the filmogenic solution, due to its effects as an outer membrane permeabilization agent that can promote the release of lipopolysaccharides from the bacterium cell membrane. Thus, in the present study, it was determined a minimal inhibitory concentration of AMC, $90 \mathrm{AU} / \mathrm{mL}$, with EDTA, $0.05 \mathrm{M}$, which hindered the growth of E. coli, S. aureus and L. monocytogenes in BHI medium (Figure 1). In the past,
A

1

2

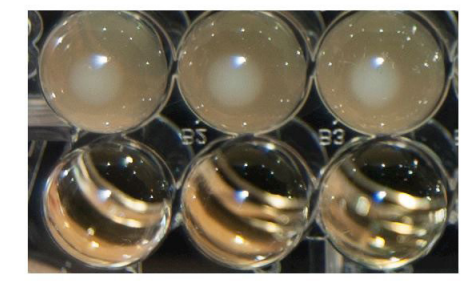

3

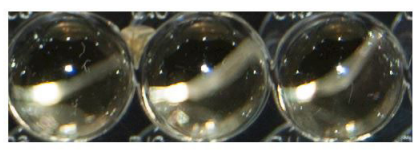

B
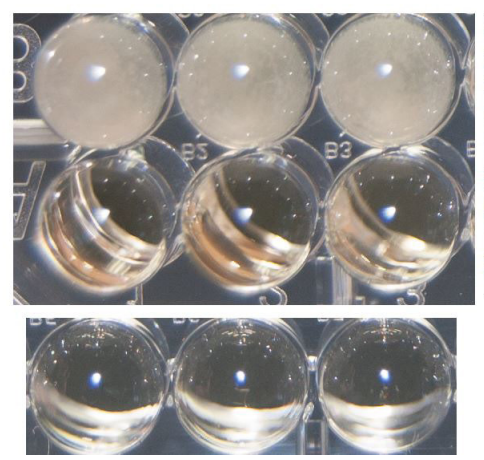

C

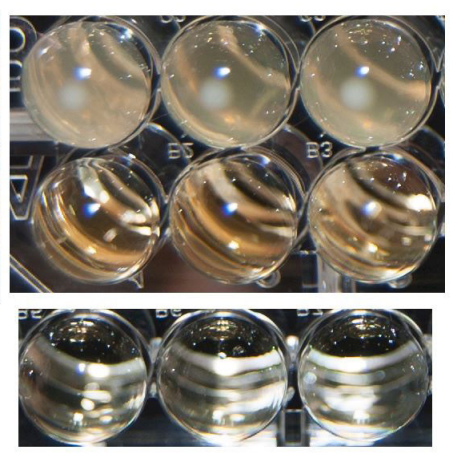

Figure 1. Minimal inhibitory concentration of AMC with EDTA for (A) Escherichia coli; (B) Staphylococcus aureus; and (C) Listeria monocytogenes in BHI, incubated at $35^{\circ} \mathrm{C}$ for $24 \mathrm{~h}$. Key: (1) AMC, $0 \mathrm{AU} / \mathrm{mL}$; EDTA, 0 M; (2) abiotic control; (3) AMC, 90 AU/mL; EDTA, $0.05 \mathrm{M}$. 
other groups have tried combinations of EDTA with conventional antimicrobials to hinder the growth of both Gram-positive and Gram-negative bacteria in various systems. For example, Sinigaglia et al. (2008) tested conditioning brines with $0.25 \mathrm{~g} / \mathrm{L}$ lysozyme and 10-50 $\mathrm{mM} \mathrm{Na}$-EDTA in mozzarella cheese, reporting a significant inhibition of spoilage microorganisms, including coliforms. In other report, Economou et al. (2009) found that the combination of 500-1500 IU nisin with $50 \mathrm{mM}$ EDTA affected the growth of Enterobacteriaceae in chicken meat. Additionally, Banin et al. (2006) found a synergic effect of Gentamicin $(10 \mathrm{mg} / \mathrm{mL})$ and EDTA $50 \mathrm{mM}$ which hinder the growth of Pseudomonas aeruginosa.

Once an effective antimicrobial activity was obtained by combination of AMC, $90 \mathrm{AU} / \mathrm{mL}$, with EDTA, $0.05 \mathrm{M}$, the functional films were elaborated keeping a constant EDTA concentration, $0.05 \mathrm{M}$, and testing three levels of AMC: 75, 90 and $120 \mathrm{AU} / \mathrm{mL}$. The film matrix contained two biopolymers: low-methoxyl pectin that promotes gelation mainly due to calcium bridge ionic bonds between carboxylic groups belonging to different chains in close contact with each other (Thakur et al., 1997); and deacetylated gellan gum that develops strong gels in presence of calcium ions (Pérez-Campos et al., 2012).

Figure 2 shows the main results concerning the growth of the tested bacteria in selective media: E. coli-MacConkey agar; S. aureus-Baird Parker medium, and L. monocytogenes-Oxford medium, in contact with the functional films. The three bacteria grew well in control plates (NF, inoculated culture media with no films), where the counts were $78 \mathrm{CFU} /$ plate and $105 \mathrm{CFU} /$ plate for E. coli and L. monocytogenes after 2 days of incubation, respectively, while $S$. aureus exhibited $77 \mathrm{CFU} /$ plate at the third day. These colony counts remained without significant changes till the end of the experiments. On the contrary, all film treatments (i.e., FC, F1, F2 and F3) hindered any bacterial growth during a 30 day-incubation period (Figure 2). Using an analogous approach, Mendoza-Mendoza et al. (2013) tested the antimicrobial activity of caseinate films with and without $S$. infantarius-AMC, reporting that films without AMC could not hinder the growth of L. monocytogenes in Oxford agar at $35{ }^{\circ} \mathrm{C}$ for $70 \mathrm{~h}$; nonetheless, the antilisterial activity was effective when AMC was incorporated into the caseinate films, suggesting that caseinate alone has no antimicrobial activity against $L$. monocytogenes.

In the present work, the antimicrobial effects of the films would be attributed to a synergic interaction of AMC, EDTA and a probable contribution of gellan gum and pectin (i.e., F1, F2 and F3 treatments); nonetheless, FC films which contained gellan gum and pectin, but not AMC nor EDTA, also exhibited a notable antimicrobial activity, that would be related with the reported antimicrobial properties exhibited by several carbohydrate polymers (i.e, karaya gum, chitosan, algal polysaccharides (Ramawat \& Mérillon, 2015); particularly, it has been reported the antimicrobial activity of pectins extracted from
A

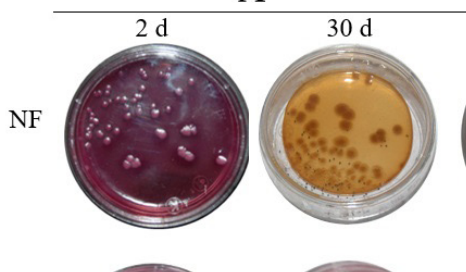

FC

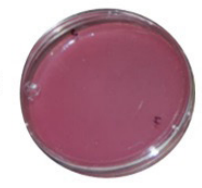

F1

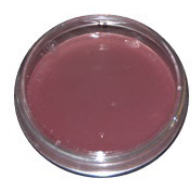

F2

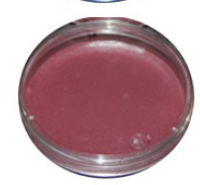

F3

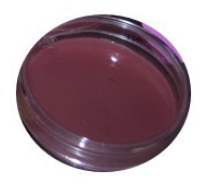

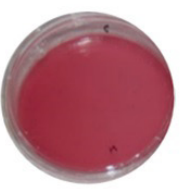
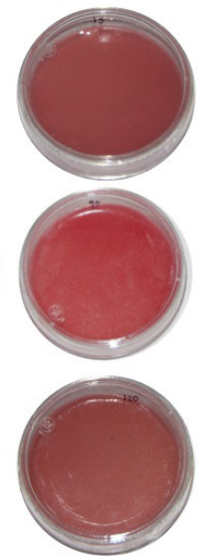

B
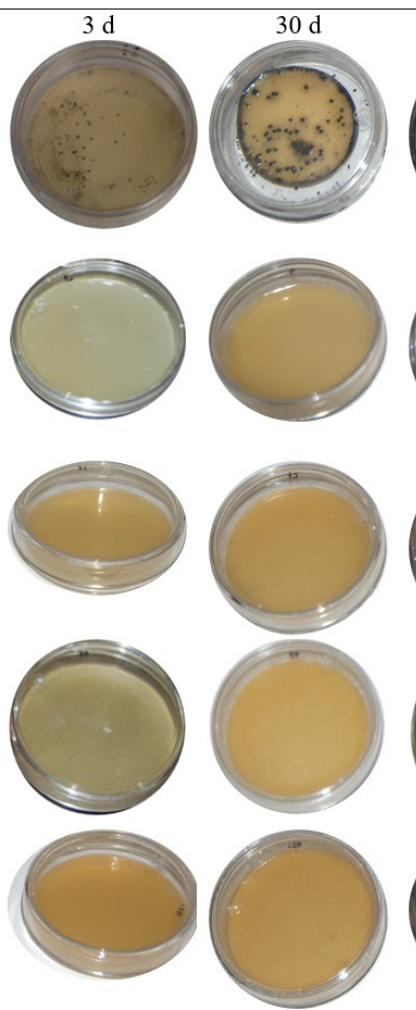

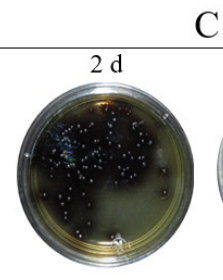

$\mathrm{C}$
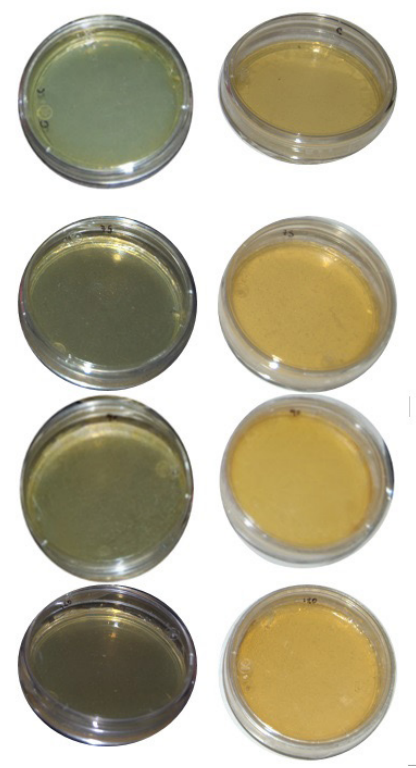

Figure 2. Growth of the tested bacteria in selective media at $25^{\circ} \mathrm{C}$ and 2 or 3 , and 30 days of incubation time. (A) Escherichia coli-MacConkey agar; (B) Staphylococcus aureus-Baird Parker medium; and (C) Listeria monocytogenes-Oxford medium. The bacteria grew well in NF plates (only culture media, no films). No bacterial growth was apparent in plates with films FC (base films containing pectin and gellan gum), as well as with films F1, F2 and F3, which were elaborated with base film-forming solution, EDTA $0.05 \mathrm{M}$, plus AMC at 75, 90 and 120 AU/mL, respectively. 
apple peel (both pristine and modified samples) against $E$. coli and S. aureus (Calce et al., 2014), as well as that of Aegle marmelos fruit against Bacillus cereus and E. coli (Jindal et al., 2013). The antimicrobial activity exhibited by the FC films would be attributed mainly to its pectin content, directly associated to the uronic acid content within the polymer (Jindal et al., 2013), as well as the degree of esterification of carboxyl group of galacturonic acid in pectin molecules (Krivorotova et al., 2017). Gullón et al. (2013) also have attributed valuable antimicrobial effects to the pectic oligosaccharides.

Based on the bacterial growth inhibition obtained in the films-selective media experiments, it was decided to test only the F2 and FC treatments in MCh medium experiments. Figure 3 shows the effects of functional films on the growth of E. coli, S. aureus and L. monocytogenes in MCh medium.

The three tested bacteria grew well in cheese medium plates with no films (Figure 3, circle symbols). During the first day of incubation, they exhibited maximum growth rates, $\mu_{\text {max }}$, for E. coli, $0.27 \mathrm{~h}^{-1}\left(\equiv 6.58\right.$ day $\left.^{-1} ; \mathrm{r}^{2}=0.99\right) ;$ S. aureus, $0.17 \mathrm{~h}^{-1}\left(\equiv 4.19\right.$ day $^{-1}$; $\left.\mathrm{r}^{2}=0.99\right)$; and $L$. monocytogenes, $0.12 \mathrm{~h}^{-1}\left(\equiv 2.84\right.$ day $\left.^{-1} ; \mathrm{r}^{2}=0.99\right)$. Furthermore, the bacteria achieved maximal concentrations $\left(\mathrm{X}_{\max }\right)$ and multiplication factors $\left(\mathrm{X}_{\max } / \mathrm{X}_{0}\right)$ of $6.4 \times 10^{8} \mathrm{CFU} / \mathrm{g}$ and
$\mathrm{X}_{\max } / \mathrm{X}_{0}=\left(6.4 \times 10^{8}\right) /\left(9.9 \times 10^{1}\right)=6.5 \times 10^{6}$ times; $1.1 \times 10^{9} \mathrm{CFU} / \mathrm{g}$ and $\left(1.1 \times 10^{9}\right) /\left(9.9 \times 10^{1}\right)=1.1 \times 10^{7}$ times, and $1.7 \times 10^{7} \mathrm{CFU} / \mathrm{g}$ and $\left(1.7 \times 10^{7}\right) /\left(9.0 \times 10^{1}\right)=1.9 \times 10^{5}$ times, for E. coli, S. aureus and $L$. monocytogenes, respectively. The bacteria were cultured in a complex medium, MCh medium, containing an average of $0.84 \%(\mathrm{w} / \mathrm{v})$ protein and $0.1 \%(\mathrm{w} / \mathrm{v})$ fat (Hnosko et al., 2009), that supported a vigorous microbial growth involving increments of 6 to $7 \log$ cycles in the bacterial concentrations.

On the other hand, in contrast of what occurred in selective medium cultures (Figure 2), the FC films exhibited a moderate antimicrobial activity against the three bacteria inoculated in MCh medium (Figure 3, triangle symbols). The corresponding calculated values of the average $\mu_{\max }$ during the FC experiments, were 0.19 day $^{-1}\left(r^{2}=0.86\right), 0.17$ day $^{-1}\left(r^{2}=0.73\right)$ and 0.26 day $^{-1}\left(r^{2}=0.83\right)$ for E. coli, S. aureus and L. monocytogenes, respectively, which suggested moderate unfavourable conditions for the growth of the bacteria in these systems. In fact, within FC-MCh systems the tested bacteria achieved final concentrations and multiplication factors of $2.1 \times 10^{2} \mathrm{CFU} / \mathrm{g}$ and $\left(2.1 \times 10^{2}\right) /\left(1.0 \times 10^{1}\right)=2.1 \times 10^{1}$ times; $2.3 \times 10^{2} \mathrm{CFU} / \mathrm{g}$ and $\left(2.3 \times 10^{2}\right) /\left(2.2 \times 10^{1}\right)=1.0 \times 10^{1}$ times, and $5.1 \times 10^{2} \mathrm{CFU} / \mathrm{g}\left(5.1 \times 10^{2}\right) /\left(1.5 \times 10^{1}\right)=3.5 \times 10^{1}$ times, for E. coli, S. aureus and L. monocytogenes, respectively, involving increments in the bacterial concentrations of merely 1 log cycle.
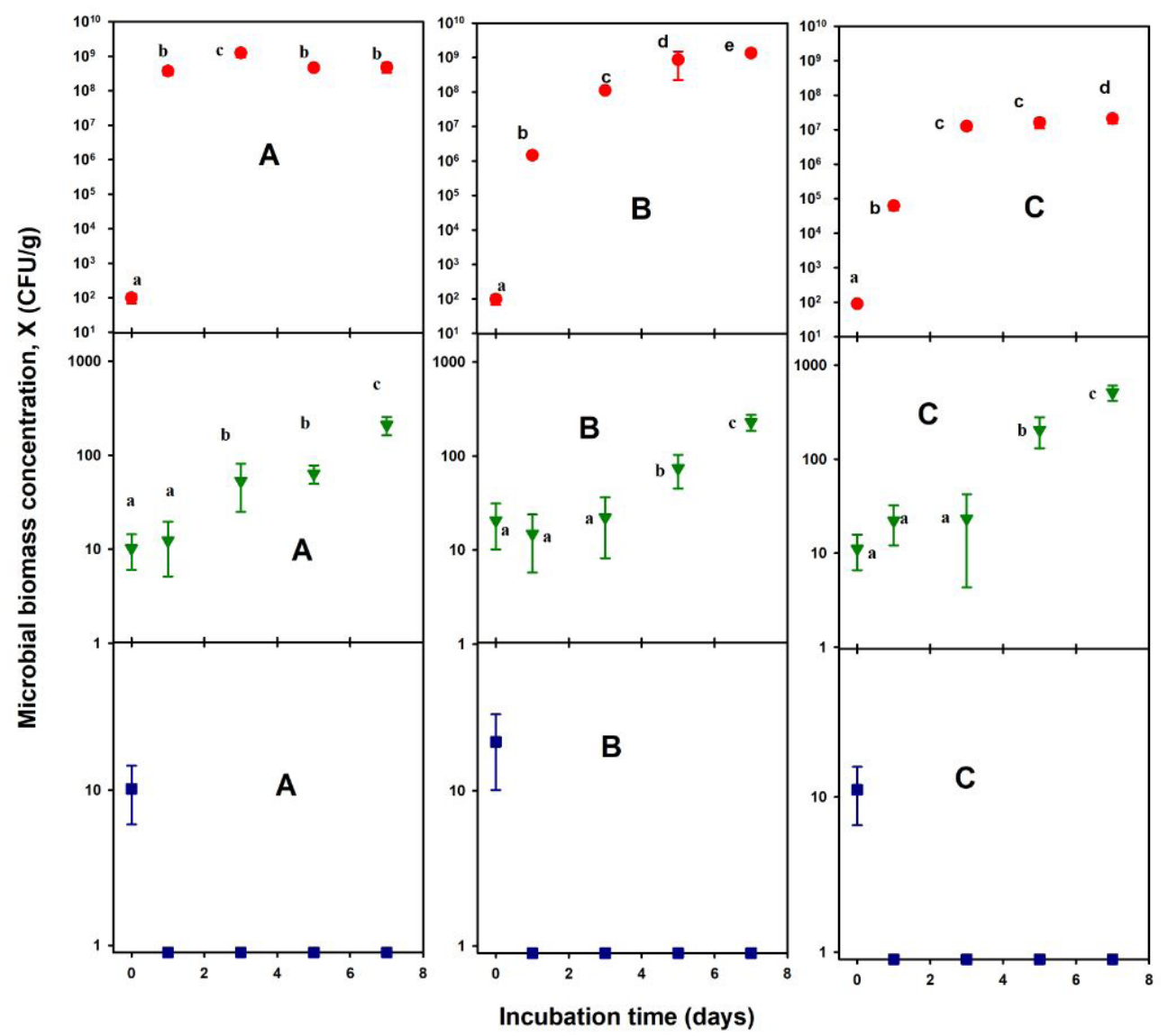

Figure 3. Growth kinetics of the tested bacteria (CFU/g) at $35^{\circ} \mathrm{C}$ in a Mexican fresh cheese medium. (A) Escherichia coli; (B) Staphylococcus aureus, and (C) Listeria monocytogenes. Film treatments were: (口) F2 film (base films containing pectin and gellan gum, plus AMC, 90 AU/mL, and EDTA, 0.05 M); ( $)$ FC films (base films), and ( ) bacterium inoculated culture media with no films. Runs were done by triplicate. Error bars are standard deviations, and same lower case letters indicate no statistical differences on the basis of Tukey's means comparison, $\mathrm{P}<0.05$. 
According to the former data, the moderate inhibition of the bacteria by FC films would be attributed to the antimicrobial effects of pectins within the films; nonetheless, the antimicrobial effectiveness would be influenced by the combination of diverse factors, including both physical and biochemical hurdles.

Moreover, an interesting antimicrobial activity was exhibited by the F2 films in MCh medium, which completely hindered the growth of the three tested bacteria during the experiments (Figure 3, square symbols) although they were inoculated in an enriched medium and incubated at optimal temperature (i.e., $35^{\circ} \mathrm{C}$ ). This bacterial growth inhibition would be due to a synergistic combination of the antimicrobial agents (i.e., AMC, EDTA and pectins) present in the active F2 films which resulted in an effective antimicrobial film. In an analogous study, Sivarooban et al. (2008) described a maximum antimicrobial activity of soy protein films added with grape seed extract $(1 \% \mathrm{w} / \mathrm{w})$, nisin $(10,000 \mathrm{IU} / \mathrm{g})$ and EDTA $(0.16 \% \mathrm{w} / \mathrm{w})$ which reduced the growth of L. monocytogenes, E. coli and Salmonella typhimurium. Also, Tajik et al. (2014) tested combinations of monolaurin and EDTA, from 250 to $2000 \mu \mathrm{g} / \mathrm{mL}$, against E. coli and S. aureus in Iranian white cheese, obtaining reductions in the bacterial concentrations.

\subsection{Mechanical characterization}

Table 1 presents the selected physical-mechanical properties of both bioactive (F2) and control (FC) films, exhibiting parameters statistically different $(\mathrm{P}<0.001)$ between the two films. The addition of EDTA and AMC into the films increased the Young's modulus (EM), then F2 showed more resistance to axial deformation than FC. Hence, F2 was almost five times less extensible than FC, and the stress value at the end of the stretching of the FC was higher than that of the F2 film. The high stiffness of the bioactive film can be ascribed to the development of a heterogeneous film structure, probably due to the formation of crystals composed of calcium and $\mathrm{H}_{2} \mathrm{EDTA}^{-2}$ ions and water molecules (Zabel et al., 2006), which could be formed during either drying or storage of the films. This effect was not expected; $\mathrm{CaCl}_{2}$ was added to filmogenic solutions to promote gellan and pectin gelation and to yield biopolymer matrices with higher degree of cross-linking and therefore less gas-permeable films. High values of mechanical properties have been also reported for other bioactive films, for instance, pectin-polylactic acid-nisin films $\left(\mathrm{EM}=2590 \mathrm{MPa}, \% \mathrm{E}_{\max }=3 \%\right)$ (Jin et al., 2009), chitosan-eugenol and chitosan-cinnamon essential oil $\left(\mathrm{EM}=1660\right.$ to $1460 \mathrm{MPa}, \% \mathrm{E}_{\max }=6$ to $\left.8 \%\right)$ (Valencia-Sullca et al., 2016) and antimicrobial gelatin films reinforced with metallic nanoparticles (EM $=2.30$ to $2.63 \mathrm{GPa}$, $\% \mathrm{E}_{\max }=8.3$ to $9 \%$ ) (Shankar et al., 2016).

\subsection{Water vapour permeability}

The values of water vapour permeability, WVP, of both FC and F2 films are shown in Table 1, being statistically significant different between them $(\mathrm{P}<0.001)$. The WVP was affected by the incorporation of antimicrobial agents, mainly EDTA, then F2 film was near $85 \%$ less water-vapour permeable than FC. This decrease might be explained by structural modifications arose in the F2 network by the development of crystal aggregates of EDTA-calcium. This assumption is based on the reported observations in studies regarding films containing nanoparticles (i.e., nanoclays, nanofibers, nanowhiskers (Sanchez-Garcia et al., 2010). These studies have attributed the reduction in WVP of nanocomposite films to the high nanodispersion of the particles across the matrix, the high crystallinity and the good interfacial adhesion in the nanobiocomposites. However, it has been also reported that at high concentration of nanoparticles, the WVP increases due to the development of filler agglomeration, which usually yield the creation of preferential paths for the permeants to diffuse faster. Thus, the good dispersion of fillers into the biopolymer matrix as well as the amount and nature of the plasticizers could be relevant aspects to consider enhancing the water barrier properties of the films.

\subsection{Oxygen permeability}

The oxygen permeability $\left(\mathrm{PO}_{2}\right)$ of the films was not affected by the presence of EDTA and AMC (Table 1). There were not a statistically significant difference between the oxygen permeability of the two films $(\mathrm{P}=0.358)$. These values were lower than the corresponding WVP ones. The hydrophilic nature of the pectin-gellan films, their low plasticisation and their microstructural organization, provided a good barrier to oxygen diffusion and this could have enhanced the antimicrobial activity of these films, reported in previous sections.

\section{Conclusion}

Food-packaging films containing gellan gum, citric pectin, glycerol, $\mathrm{CaCl}_{2}$, EDTA and antimicrobial activity-concentrated supernatant (AMC) from Streptococcus infantarius-fermentations, which contained bacteriocin-like inhibitory substances, were elaborated and characterized. The bioactive films exhibited interesting inhibitory effects on Escherichia coli, Staphylococcus aureus and Listeria monocytogenes, inoculated in both selective media

Table 1. Selected physical-mechanical properties of functional films. The control film (FC) contained $0.2 \%(\mathrm{w} / \mathrm{v})$ gellan gum, $1 \%$ (w/v) citric pectin, $0.5 \%$ (w/v) glycerol and $\mathrm{CaCl}_{2} 5 \mathrm{mM}$. F2 treatment: FC formula plus AMC, $90 \mathrm{AU} / \mathrm{mL}$, and EDTA, $0.05 \mathrm{M}$. Mean values \pm standard deviation.

\begin{tabular}{ccc}
\hline Properties & FC & F2 \\
\hline Young's modulus (MPa) & $707 \pm 48 \mathrm{a}$ & $1,394 \pm 144 \mathrm{~b}$ \\
Elongation at break (\%) & $9 \pm 2 \mathrm{~b}$ & $1.9 \pm 0.4 \mathrm{a}$ \\
Stress at break $(\mathrm{MPa})$ & $13 \pm 1 \mathrm{~b}$ & $5.7 \pm 0.7 \mathrm{a}$ \\
$\left.\mathrm{WVP}^{-11} \mathrm{~g} \mathrm{~m} \mathrm{~Pa}^{-1} \mathrm{~s}^{-1} \mathrm{~m}^{-2}\right)$ & $19.8 \pm 0.4 \mathrm{~b}$ & $2.9 \pm 0.8 \mathrm{a}$ \\
$\mathrm{PO}_{2}\left(10^{-12} \mathrm{~g} \mathrm{~m} \mathrm{~Pa}^{-1} \mathrm{~s}^{-1} \mathrm{~m}^{-2}\right)$ & $1.2 \pm 0.2 \mathrm{a}$ & $2 \pm 1 \mathrm{a}$ \\
\hline
\end{tabular}

Values in the same row with different letters are statistically different $(\mathrm{p} \leq 0.001$; $\mathrm{t}$-test). 
(MacConkey, Baird Parker and Oxford, respectively) and in a Mexican fresh cheese medium, where such antimicrobial activity would be attributed to an AMC-EDTA-Pectin synergy. On the other hand, the physical-mechanical properties of the films were influenced by the EDTA contents, yielding stronger and less extensible films than the control one; these effects might be attributed to the formation of EDTA-calcium crystals into the film biopolymer matrix. These crystals also enhanced the water barrier properties of the bioactive films. Besides, the films showed low oxygen permeabilities, which would contribute to their antimicrobial effectiveness.

\section{Acknowledgements}

PYJV acknowledged CONACyT MSc. Scholarship. The authors thanked Dr. C Wacher and Dr. G. Ruiz for providing the bacterial strains and for helpful discussions. This work was supported by the CONACyT-México under Grants INFRA 2014, No. 230138; INFRA 2015, No. 254437, and INFRA 2016, No. 269805; and PRODEP-SEP-México under Grant Red CAs 2016/2017 "Diseño y Caracterización de Películas Alimentarias a base de Biopolímeros y Antimicrobianos Naturales". The authors are grateful to Ing. A. Torres-Blancas for help in the English revision of the manuscript.

\section{References}

Aguirre-Loredo, R. Y., Rodríguez-Hernández, A. I., \& ChavarríaHernández, N. (2014). Physical properties of emulsified films based on chitosan and oleic acid. CYTA: Journal of Food, 12(4), 305-312. http://dx.doi.org/10.1080/19476337.2013.853207.

Aider, M. (2010). Chitosan application for active bio-based films production and potential in the food industry. LebensmittelWissenschaft + Technologie, 43(6), 837-842. http://dx.doi.org/10.1016/j. lwt.2010.01.021.

American Society for Testing and Materials - ASTM. (1982). D1434-82: standard test method for determining gas permeability characteristics of plastic film and sheeting. Philadelphia: ASTM.

American Society for Testing and Materials - ASTM. (1993). D638M-93: standard test method for tensile properties of plastics (metric). Philadelphia: ASTM.

American Society for Testing and Materials - ASTM. (2000). E96-00: standard test methods for water vapor transmission of materials. Philadelphia: ASTM.

American Society for Testing and Materials - ASTM. (2010). D882-10: standard test method for tensile properties of thin plastic sheeting. Philadelphia: ASTM.

Banin, E., Brady, K. M., \& Greenberg, E. P. (2006). Chelator-induced dispersal and killing of Pseudomonas aeruginosa cells in a biofilm. Applied and Environmental Microbiology, 72(3), 2064-2069. http:// dx.doi.org/10.1128/AEM.72.3.2064-2069.2006. PMid:16517655.

Calce, E., Mignogna, E., Bugatti, V., Galdiero, M., Vittoria, V., \& De Luca, S. (2014). Pectin functionalized with natural fatty acids as antimicrobial agent. International Journal of Biological Macromolecules, 68, 28-32. http://dx.doi.org/10.1016/j.ijbiomac.2014.04.011. PMid:24751510.

Calderón-Aguirre, Á.-G., Chavarría-Hernández, N., Mendoza-Mendoza, B., Vargas-Torres, A., García-Hernández, E., \& Rodríguez-Hernández, A.-I. (2015). Antilisterial activity and physical-mechanical properties of bioactive caseinate films. CYTA: Journal of Food, 13(4), 483-490. http://dx.doi.org/10.1080/19476337.2014.1003200.
Campos, C. A., Gerschenson, L. N., \& Flores, S. K. (2010). Development of edible films and coatings with antimicrobial activity. Food and Bioprocess Technology, 4(6), 849-875. http://dx.doi.org/10.1007/ s11947-010-0434-1.

Durch, J., Ringhand, T., Manner, K., Barnett, M., Proctor, M., AhrabiFard, S., Davis, J., \& Boxrud, D. (2000). Outbreak of Escherichia coli O157:H7 infection associated with eating fresh cheese curdsWisconsin, June 1998. MMWR. Morbidity and Mortality Weekly Report, 49(40), 911-913. PMid:11043645.

Economou, T., Pournis, N., Ntzimani, A., \& Savvaidis, I. N. (2009). Nisin-EDTA treatments and modified atmosphere packaging to increase fresh chicken meat shelf-life. Food Chemistry, 114(4), 14701476. http://dx.doi.org/10.1016/j.foodchem.2008.11.036.

Fretz, R., Pichler, J., Sagel, U., Much, P., Ruppitsch, W., Pietzka, A. T., Stöger, A., Huhulescu, S., Heuberger, S., Appl, G., Werber, D., Stark, K., Prager, R., Flieger, A., Karpíšková, R., Pfaff, G., \& Allerberger, F. (2010). Update: multinational listeriosis outbreak due to 'Quargel', a sour milk curd cheese, caused by two different $L$. monocytogenes serotype 1/2a strains, 2009-2010. Eurosurveillance, 15(16), 1-2. PMid:20430003.

Gullón, B., Gómez, B., Martínez-Sabajanes, M., Yáñez, R., Parajó, J. C., \& Alonso, J. L. (2013). Pectic oligosaccharides: manufacture and functional properties. Trends in Food Science \& Technology, 30(2), 153-161. http://dx.doi.org/10.1016/j.tifs.2013.01.006.

Hnosko, J., Clark, S., \& Van Hekken, D. (2009). Latin American cheeses. In S. Clark, M. Costello, M. Drake \& F. Bodyfelt (Eds.), The sensory evaluation of dairy products (pp. 489-504). New York: Springer US.

Jin, T., Liu, L., Zhang, H., \& Hicks, K. (2009). Antimicrobial activity of nisin incorporated in pectin and polylactic acid composite films against Listeria monocytogenes. International Journal of Food Science \& Technology, 44(2), 322-329. http://dx.doi.org/10.1111/j.13652621.2008.01719.x.

Jindal, M., Kumar, V., Rana, V., \& Tiwary, A. K. (2013). Aegle marmelos fruit pectin for food and pharmaceuticals: Physico-chemical, rheological and functional performance. Carbohydrate Polymers, 93(2), 386-394. http://dx.doi.org/10.1016/j.carbpol.2012.12.012. PMid:23499073.

Kérouanton, A., Hennekinne, J. A., Letertre, C., Petit, L., Chesneau, O., Brisabois, A., \& De Buyser, M. L. (2007). Characterization of Staphylococcus aureus strains associated with food poisoning outbreaks in France. International Journal of Food Microbiology, 115(3), 369-375. http://dx.doi.org/10.1016/j.ijfoodmicro.2006.10.050. PMid:17306397.

Krivorotova, T., Staneviciene, R., Luksa, J., Serviene, E., \& Sereikaite, J. (2017). Impact of pectin esterification on the antimicrobial activity of nisin-loaded pectin particles. Biotechnology Progress, 33(1), 245251. http://dx.doi.org/10.1002/btpr.2391. PMid:27792287.

López-Cuellar, M. del R., Rodríguez-Hernández, A. I., \& ChavarríaHernández, N. (2016). LAB bacteriocin applications in the last decade. Biotechnology, Biotechnological Equipment, 30(6), 1039-1050. http://dx.doi.org/10.1080/13102818.2016.1232605.

López-Ortega, M. A. (2014). Producción de sustancias con actividad antimicrobiana de uso potencial en la industria de alimentos, mediante el cultivo de bacterias ácido lácticas usando medios de cultivo alternativos (Maestría). Universidad Autónoma del Estado de Hidalgo, Tulancingo, Hgo. México.

Magalhães, R., Almeida, G., Ferreira, V., Santos, I., Silva, J., Mendes, M. M., Pita, J., Mariano, G., Mâncio, I., Sousa, M. M., Farber, J., Pagotto, F., \& Teixeira, P. (2015). Cheese-related listeriosis outbreak, Portugal, March 2009 to February 2012. Eurosurveillance, 20(17), 6. http:// dx.doi.org/10.2807/1560-7917.ES2015.20.17.21104. PMid:25955775. 
Marques, J. L., Funck, G. D., Dannenberg, G. D., Cruxen, C. E., Halal, S. L., Dias, A. R., Fiorentini, A. M., \& Silva, W. P. (2017). Bacteriocinlike substances of Lactobacillus curvatus P99: characterization and application in biodegradable films for control of Listeria monocytogenes in cheese. Food Microbiology, 63, 159-163. http://dx.doi.org/10.1016/j. fm.2016.11.008. PMid:28040164.

Mendoza-Mendoza, B., Rodríguez-Hernández, A. I., Vargas-Torres, A., Díaz-Ruiz, G., Montiel, R., Ramos-Aboites, H. E., Castro-Rosas, J., \& Chavarría-Hernández, N. (2013). Characterization of the effects on the growth kinetics of Listeria monocytogenes in solid culture in contact with caseinate base edible films added with antilisterial activity from Streptococcus sp. ABMX isolated from Pozol, an indigenous Mexican beverage. International Food Research Journal, 20(5), 2917-2925.

Nuñez, M., Tomillo, J., Gaya, P., \& Medina, M. (1996). Bacteriocin quantification by the critical dilution method: a comparison af arbitrary units with diameter and area of the zone of growth inhibition. Milchwissenschaft. Milk Science International, 51(1), 7-10.

Ollé Resa, C. P., Gerschenson, L. N., \& Jagus, R. J. (2016). Starch edible film supporting natamycin and nisin for improving microbiological stability of refrigerated argentinian Port Salut cheese. Food Control, 59, 737-742. http://dx.doi.org/10.1016/j.foodcont.2015.06.056.

Otero, V., Becerril, R., Santos, J. A., Rodríguez-Calleja, J. M., Nerín, C., \& García-López, M.-L. (2014). Evaluation of two antimicrobial packaging films against Escherichia coli O157:H7 strains in vitro and during storage of a Spanish ripened sheep cheese (Zamorano). Food Control, 42, 296-302. http://dx.doi.org/10.1016/j.foodcont.2014.02.022.

Pérez-Campos, S. J., Chavarría-Hernández, N., Tecante, A., Ramírez-Gilly, M., \& Rodríguez-Hernández, A. I. (2012). Gelation and microstructure of dilute gellan solutions with calcium ions. Food Hydrocolloids, 28(2), 291-300. http://dx.doi.org/10.1016/j.foodhyd.2012.01.008.

Ramawat, K. G., \& Mérillon, J. M. (Eds.). (2015). Polysaccharides: bioactivity and biotechnology. Switzerland: Springer International Publishing.

Sanchez-Garcia, M. D., Lopez-Rubio, A., \& Lagaron, J. M. (2010). Natural micro and nanobiocomposites with enhanced barrier properties and novel functionalities for food biopackaging applications. Trends in Food Science \& Technology, 21(11), 528-536. http://dx.doi. org/10.1016/j.tifs.2010.07.008.

Sánchez-Reyes, W. Y. (2014). Producción de sustancias con actividad antimicrobiana de uso potencial en la industria alimentaria, mediante el cultivo de la bacteria ácido láctica, Streptococcus infantarius, en medios complejos que contienen melazas (Maestría). Universidad Autónoma del Estado de Hidalgo, Tulancingo, Hgo. México.

Shankar, S., Jaiswal, L., Selvakannan, P. R., Ham, K. S., \& Rhim, J. W. (2016). Gelatin-based dissolvable antibacterial films reinforced with metallic nanoparticles. RSC Advances, 6(71), 67340-67352. http:// dx.doi.org/10.1039/C6RA10620J.

Silk, B. J., Mahon, B. E., Griffin, P. M., Gould, L. H., Tauxe, R. V., Crim, S. M., Jackson, K. A., Gerner-Smidt, P., Herman, K. M., \& Henao, O. L. (2013). Vital signs: Listeria illnesses, deaths, and outbreaksUnited States, 2009-2011. MMWR. Morbidity and Mortality Weekly Report, 62(22), 448-452. PMid:23739339.

Sinigaglia, M., Bevilacqua, A., Corbo, M. R., Pati, S., \& Del Nobile, M. A. (2008). Use of active compounds for prolonging the shelf life of mozzarella cheese. International Dairy Journal, 18(6), 624-630. http://dx.doi.org/10.1016/j.idairyj.2007.11.022.

Sivarooban, T., Hettiarachchy, N. S., \& Johnson, M. G. (2008). Physical and antimicrobial properties of grape seed extract, nisin, and EDTA incorporated soy protein edible films. Food Research International, 41(8), 781-785. http://dx.doi.org/10.1016/j.foodres.2008.04.007.

Tajik, H., Raeisi, M., Rohani, S. M. R., Hashemi, M., Zare, M. A., Naghili, H., Rozbani, D., \& Ammar, D. B. (2014). Effect of monolaurin alone and in combination with EDTA on viability of Escherichia coli and Staphylococcus aureus in culture media and iranian white cheese. Journal of Food Quality and Hazards Control, 1(4), 108-112.

Tavera-Montes, F. L. (2010). Producción de bacteriocinas a partir de bacterias ácido lácticas aisladas de pozol para la inhibición de bacterias patógenas (Tesis). Universidad Nacional Autónoma de México, México.

Thakur, B. R., Singh, R. K., \& Handa, A. K. (1997). Chemistry and uses of pectin: a review. Critical Reviews in Food Science and Nutrition, 37(1), 47-73. http://dx.doi.org/10.1080/10408399709527767. PMid:9067088.

Vaara, M. (1992). Agents that increase the permeability of the outer membrane. Microbiological Reviews, 56(3), 395-411. PMid:1406489.

Valencia-Sullca, C., Jiménez, M., Jiménez, A., Atarés, L., Vargas, M., \& Chiralt, A. (2016). Influence of liposome encapsulated essential oils on properties of chitosan films. Polymer International, 65(8), 979-987. http://dx.doi.org/10.1002/pi.5143.

Wiegand, I., Hilpert, K., \& Hancock, R. E. (2008). Agar and broth dilution methods to determine the minimal inhibitory concentration (MIC) of antimicrobial substances. Nature Protocols, 3(2), 163-175. http:// dx.doi.org/10.1038/nprot.2007.521. PMid:18274517.

Youssef, A. M., El-Sayed, S. M., El-Sayed, H. S., Salama, H. H., \& Dufresne, A. (2016). Enhancement of Egyptian soft white cheese shelf life using a novel chitosan/carboxymethyl cellulose/zinc oxide bionanocomposite film. Carbohydrate Polymers, 151, 9-19. http:// dx.doi.org/10.1016/j.carbpol.2016.05.023. PMid:27474538.

Zabel, M., Poznyak, A. L., \& Pawlowski, V. I. (2006). Crystal structure of calcium dihydroethylenediaminetetraacetate(2-) dihydrate $\mathrm{Ca}(\mathrm{H} 2 \mathrm{Edta}) \cdot 2 \mathrm{H} 2 \mathrm{O}$. Journal of Structural Chemistry, 47(3), 581-584. http://dx.doi.org/10.1007/s10947-006-0341-5. 